\title{
A presença da "religião" na literatura: uma questão de participação estética?
}

\author{
Douglas Rodrigues da Conceição*
}

\section{Resumo}

Perguntando pelo estatuto da "religião" quando sua transparência se torna inequívoca na tessitura dos textos literários, este ensaio pretende ser uma contribuição ao campo de estudos que toma as relações entre religião e literatura como sua principal tarefa. Seguindo algumas provocações de Susan Sontag (2020) e após evocar, principalmente, o pensamento de Gérard Genette (2010), propomos, mesmo que de modo provisório e operacional, a noção de participação estética da religião como material artístico-literário. Com a finalidade de oferecer ilustrações acerca dessa possível função realizada pela "religião" quando presente nas criações literárias, empregamos três escritos de Woody Allen reunidos sob o título The Scrolls, que estão coligidos em Without Feathers (1975). Tais ilustrações são apresentadas com aportes teóricos provenientes de Gérard Genette (1982) e Dominique Maingueneau (2009).

Palavras-chaves: Religião e literatura; participação estética; linguagem verbal; Woody

\section{Allen.The presence of "religion" in literature: a matter of aesthetic participation?}

\section{Abstract}

Asking about the status of "religion" when its transparency becomes unequivocal in the structure of literary texts, this essay intends to be a contribution to the field of studies that takes the relations between religion and literature as its main task. Carrying on some provocations made by Susan Sontag (2020) and evoking mainly Gérard Genette's thinking (2010), we propose, even if in a provisional and operational way, the notion of aesthetic participation of religion as an artistic-literary material. In order to offer some illustrations about this possible function performed by "religion" when present in literary creations, we employ three writings by Woody Allen gathered under the title The Scrolls, which are collected in his Without Feathers (1975). These illustrations are presented with theoretical contributions from Gérard Genette (1982) and Dominique Maingueneau (2009).

Keywords: Religion and literature; aesthetic participation; verbal language; Woody Allen.

* Doutor em Ciências da Religião pela UMESP. Professor da Universidade do Estado do Pará. E-mail: abismos@gmail.com 


\section{La presencia de la "religión" en la literatura: ¿una cuestión de participación estética?}

\section{Resumen}

Al preguntarse por el estatuto de la "religión" cuando su transparencia se vuelve inequívoca en la estructura de los textos literarios, este ensayo pretende ser una contribución al campo de estudios que toma como tarea principal las relaciones entre religión y literatura. Retomando algunas provocaciones de Susan Sontag (2020) y evocando principalmente el pensamiento de Gérard Genette (2010), proponemos, aunque sea de forma provisional y operativa, la noción de participación estética de la religión como material artístico-literario. Para ofrecer algunas ilustraciones sobre esta posible función desempeñada por la "religion" cuando está presente en las creaciones literarias, empleamos tres escritos de Woody Allen reunidos bajo el título The Scrolls, que se recogen en Without Feathers (1975). Estas ilustraciones se presentan con las aportaciones teóricas de Gérard Genette (1982) y Dominique Maingueneau (2009).

Palabras-clave: Religión y literatura; participación estética; lenguaje verbal; Woody Allen

\section{La présence de la « religion » dans la littérature : une question de participation esthétique?}

Lorsque l'on demande le statut de la « religion » quand sa clarté devient indéniable dans la conception des textes littéraires, cet essai envisage de contribuer au champ des études qui ont mis en exergue la relation entre religion et littérature. À la suite des provocations de Susan Sontag (2020) et après avoir évoqué la pensée de Gérard Genette (2010), notamment, on propose de façon provisoire et opérationnelle la notion de participation esthétique de la religion en tant que matériau artistique-littéraire. Dans l'intention d'attribuer aux illustrations une éventuelle fonction influée par la « religion » présente dans les créations littéraires, on évoque trois textes de Woody Allen appelés The Scrolls, compilés dans l'ouvrage Without Feathers (1975). Ces illustrations ont été élaborées au moyen des supports théoriques issus de Gérard Genette (1982) et Dominique Maingueneau (2009).

Mots-clés : Religion et littérature ; participation esthétique ; langage verbal ; Woody Allen.

\section{Introdução}

A evocação da transparência da religião nos textos literários é a questão a ser discutida neste ensaio. Já na aparição do emblemático texto de M.- D. Chenu, que foi singularmente intitulado La littérature comme "lieu" de la théologie, o espectro de um modelo hermenêutico parece ter se tornado um perfil metodológico, senão aparentemente consensual, pelo menos reiteradamente retomado nos estudos que aproximam religião e literatura. Chenu apresentou o horizonte do problema nos seguintes termos: "quelle fut, quelle doit être 
la situation épistémologique de la 'littérature' en théologie?” (CHENU, 1969, p. 71). Ainda que se possa depreender diversas perspectivas da posição de Chenu, uma, no entanto, nos parece central: a literatura tornara-se alvo de um olhar quase estritamente teológico. No Brasil, o modelo investigativo desenvolvido nesse profícuo campo de estudos tem seguido, de modo geral, as inquietações seminais desenvolvidas no continente europeu, que consistem, basicamente, na identificação e na interpretação de aspectos da religião com propósitos teológicos ${ }^{1}$. Em particular, não pretendemos reduzir a um único paradigma metodológico toda produção intelectual brasileira nascida do terreno de estudos ora chamado de "teologia e literatura", ora nomeado "religião e literatura". A sua vastidão impediria uma afirmação dessa ordem. Por outro lado, seria incontornável perceber que os trabalhos pioneiros realizados do Brasil tinham, cada um a seu próprio modo, uma preocupação em estabelecer uma espécie de teologia da literatura. Esse foi o caso de trabalhos realizados por pesquisadores com grande destaque na área de teologia, ciências da religião e literatura² ${ }^{2}$.

$\mathrm{O}$ viés preponderantemente hermenêutico de uma espécie de teologia da literatura, ao menos no panorama brasileiro, trouxe-nos à lembrança as justas advertências feitas por Susan Sontag em sua crítica à interpretação como paradigma da relação com as obras de arte. Desferindo duras críticas à teoria da arte dentro do tão conhecido e amplamente difundido esquema platônico-aristotélico e apontando para a necessária reabilitação da sensibilidade como elemento fundamental da nossa relação com as expressões artísticas, Sontag postula que a redução da obra de arte à interpretação do seu conteúdo não realiza outra coisa senão a domesticação da própria obra de arte: "a interpretação torna a arte dócil, submissa" (SONTAG, 2020, p. 21).

O que o excesso de ênfase na ideia de conteúdo acarreta é o perpétuo e sempre inconcluso projeto de interpretação. E é o hábito de abordar as obras de artes a fim de interpretá-las que, reciprocamente, sustenta a fantasia de que de fato exista algo que seja o conteúdo de uma obra de arte [...].

Em Pour une histoire littéraire de l'expérience religieuse, J.-P. Jossua se perguntava o que, então, pode melhor dizer a literatura no lugar de uma teologia puramente conceitual acerca do mistério da fé e da existência cristã? Cf. JOSSUA, J.-P. Pour une histoire littéraire de l'expérience religieuse. Paris: Beauchesne, 1985. v. 1.

2 Apenas a título de exemplo, evocamos os dois importantes trabalhos de José Carlos Barcellos. Cf. BARCELLOS, José Carlos. Literatura e espiritualidade: uma leitura de Jeunes Années, de Julien Green. Bauru: EDUSC, 2001; BARCELLOS, José Carlos. O drama da salvação: espaço autobiográfico e experiência cristã. Juiz de Fora: Subiaco, 2008. 
Nossa tarefa não é descobrir o máximo de conteúdo numa obra de arte, muito menos extrair da obra de arte mais conteúdo do que já está ali. Nossa tarefa é reduzir o conteúdo, para podermos ver a coisa [...]. A função da crítica deve ser a de mostrar como ela é o que é, e mesmo é isso o que é ela é, e não o que ela significa (SONTAG, 2020, p. 18, 29).

É claro que não se trata de estabelecermos generalizações, mas, até onde o nosso olhar consegue alcançar, as aproximações entre religião e literatura - pelo menos é o que demostra um sem-número de trabalhos nesse campo de estudos - estão basicamente ancoradas em uma interpretação dos "conteúdos religiosos" latentes ou implícitos num texto literário. No caso aqui levantado, ainda que as aproximações entre religião e literatura possam partir de um princípio segundo o qual múltiplos agenciamentos podem ser estabelecidos entre elas, tal compreensão tem insistentemente servido de carta branca para uma abordagem cujo ponto final seja a oferta de uma interpretação do possível conteúdo religioso que uma obra literária, em tese, comporta. Ainda na esteira de Sontag, esse tipo de abordagem não conseguiria se desfazer ou apenas se restringiria a repetir a fórmula segundo a qual "[...] uma obra de arte, por definição, diz alguma coisa” (SONTAG, 2020, p. 17). Não por acaso, das três violações “em massa” produzidas pelas incontáveis interpretações da obra de Kafka, e que são exemplificadas por Sontag, uma tem a ver com a leitura alegórico-religiosa dos romances $O$ castelo e $O$ processo do autor tcheco. Para ela, "a proliferação de interpretações da arte envenena nossas sensibilidades" (2000, p. 21) a ponto de a interpretação tornar-se "uma vingança do intelecto contra a arte” (SONTAG,2000, p. 21). E ela vai além, o que ilustra bem a preocupação de fundo deste ensaio:

Esse filistinismo da interpretação é mais disseminado na literatura do que em qualquer outra arte. Faz décadas que os críticos creem que sua tarefa é traduzir os elementos do poema, da peça, do romance ou do conto em alguma outra coisa (SONTAG, 2000, p. 21).

\section{Na literatura, a religião...}

Se o que chamamos de religião se transparece na superfície da literatura, a ponto de termos um campo próprio de estudos consagrados a compreender o tipo de interconexão que elas estabelecem, talvez um possível caminho que nos leve a resistir à tentação interpretativa seja o de pensar a religião como um elemento ocasional da linguagem literária (e não propriamente um conteúdo) 
que, dentro do respectivo regime verbal, concorre para o cumprimento da função dominante da linguagem à qual está implicada. Poderíamos falar, assim, inicialmente, das evidentes ocorrências da religião na linguagem literária. A questão a ser levantada é a seguinte: que função realiza a religião quando se apresenta de modo transparente na literatura? Certos de que o campo de estudos chamado de religião e literatura compreende consensualmente esta última como um tipo de linguagem artística e não como outra coisa e que, como tal, se manifesta por meio de objetos particulares (obras), talvez possamos, a partir desse consenso, ter a oportunidade de assegurar para as manifestações literárias o que lhes é próprio, a saber, a sua "fonction esthétique intentionnelle", segundo Gérard Genette (2010, p. 400). O que pretendemos dizer de antemão é que diante da aproximação entre religião e literatura, a atenção que se dá à segunda (seja um poema, um conto, um romance, seja uma peça de teatro etc.) admite (ou deve admitir) que um receptor hipotético estabeleça, antes, um pacto que reconhece o estatuto artístico que lhe compete. Como bem sublinhou Genette em Fiction et diction: "Il est en effet de consensus à peu près universel, quoique souvent oublié, que la littérature, entre autres choses, est un art [...]" (GENETTE, 2004, p. 91; grifo nosso).

Desejaríamos, então, pôr na proa da discussão que se segue que o estatuto da religião para a literatura, diante da possiblidade de aproximá-las, considere que a primeira esteja implicada ao cumprimento dos caracteres dominantes da segunda. Apenas para se refletir: se Roman Jakobson (1977, p. 77) tem razão ao admitir que a noção de dominante (la dominante) pode ser definida como sendo "l'élément focal d'une œuvre d'art: elle gouverne, détermine et transforme les outres élément" (e sua atenção volta-se para o que chamou de langage versifié), seria preciso então pensar, mesmo sob uma adoção muito restrita e parcial da questão por ele levantada - sob o risco de equívocos - que função exerceria a religião (sob a hipótese de haver alguma função) quando ela se vê implicada às operações que se realizam no interior de uma obra presidida pelo regime verbal.

Conduzida para o interior das obras literárias, propomos que a religião seja pensada como matéria da expressão verbal que, enquanto tal, encampa o jogo do artístico e dos efeitos que ele promove. Mesmo sob essa hipotética "transformação" em material verbal, que em princípio a associaria ao cumprimento da função artística da obra literária, a religião não se torna totalmente opaca. Um dos sintomas dessa não-opacidade da religião, por exemplo, é o fato de que um determinado receptor, diante de uma situação 
de recepção de um texto artístico regido pelo verbal, sendo ele familiarizado com a codificação por meio da qual a religião se articula, é capaz de percebêla nesse tipo de métissage des langages (cf. LOTMAM, 1973). Muitas abordagens que são produzidas no campo de estudos chamado de religião e literatura, no fundo, não consideram esse possível nível de operação da religião quando presente no texto verbal.

A noção há pouco introduzia, qual seja, a de "fonction esthétique intentionnelle" que recuperamos Genette, pode nos abrir caminhos para pensar a possibilidade da participação da religião na malha das manifestações literárias, o que talvez nos desloque ou nos demova um pouco da tentação à interpretação, ao menos nos moldes das inquietudes de Sontag. Segundo Genette (2010), uma relação propriamente estética, de modo geral, tal como a que estabelecemos com as obras de arte, consiste em uma resposta afetiva a um objet attentionnel. Genette chama-nos atenção para a possibilidade de se distinguir o estatuto da noção de relação estética da noção de relação artística implicadas aos objetos artísticos (2010, p. 414). Não é o objeto que torna a relação com ele necessariamente uma relação estética, mas antes a relação estabelecida com ele que o torna um objeto estético. Em suma, o que dotaria um objeto do estatuto artístico é o sentimento do receptor de que esse objeto foi produzido segundo uma intencionalidade estética. Sob a condição de sua ocorrência numa obra literária, por exemplo, a convocação da religião nela implicada estaria associada a essa prospectiva intencionalidade a partir da qual o objeto conquista o seu estatuto.

Se são plausíveis as preocupações expostas por Sontag em seu brilhante opúsculo ao reivindicar maior presença da nossa "experiência sensorial" em relação às expressões artísticas (Sontag evoca a literatura, a pintura e o cinema), não veríamos problema em recuperar de Kendall Walton a noção de "propriedades perceptivas" (WALTON, 1992, p. 83). Pareceu-nos propício introduzir essa categorização, ainda que sob as advertências quanto ao seu uso para obras literárias, pois o tipo de participação que a religião realiza no interior de um texto literário tem a ver com certa conformidade a partir da qual ela passa a pertencer ao regime artístico-verbal. Talvez não fosse nenhum exagero dizer que, se considerarmos um vasto conjunto de obras literárias, a religião até poderia ser considerada como um tipo de invariante. Essa "transformação" da religião em material artístico-literário, em termos de função, pode ser pensada a partir do que chamaremos, muito provisória e precariamente, de participação estética. Os agenciamentos estabelecidos entre 
os elementos que conformam os textos literários, incluindo a religião sob convocação do ato de criação, concorreriam para o cumprimento da função artística desses tipos de texto.

Sob tal ótica, haverá participação estética quando a religião for tomada na produção do objeto artístico e estiver a serviço da sua função enquanto tal. O que desejamos apontar é que a religião, ao ser projetada para o interior do texto literário, passa a ocupar um lugar proeminente no cumprimento da função artística desse texto. A sua transparência no texto literário projeta-se sobre o receptor, mas sob o estrito cumprimento da sua função artística.

\section{"Meio-jogo..."}

Se existe algum consenso acerca dos possíveis efeitos da arte sobre os seus receptores, pareceu-nos oportuno, sob o risco de fracassar, é claro, oferecer breves ilustrações a partir das quais os efeitos reivindicados por Sontag pudessem nos servir de exemplos desse tipo de transparência da religião, os quais, de modo quase incontornável, regulam nossa atenção sobre essas expressões artísticas.

Antes de chegarmos às ilustrações propriamente ditas, no entanto, convém realizar uma curta digressão e, em seguida, justificar a inclinação aos horizontes teóricos que auxiliarão o nosso olhar sobre elas. A convocação da religião pelas expressões artísticas não se resume, como sabemos, ao universo dos textos literários; isso seria até mesmo impensável. Apenas para exemplificar, recorremos a dois casos bem recentes. Gerald Thomas, renomado dramaturgo com vertiginosa projeção internacional, certamente um dos maiores do nosso tempo, nomeou de Dilúvio sua peça de 2017. Se é possível dizer que o paratexto (GENETTE, 1982; 2009) Dilúvio pode estabelecer ${ }^{3}$ um tipo de elo, uma conversão de olhares etc. em direção ao universo mítico bíblico, que é predominantemente verbal - o que certamente precisaria ser analisado parcimoniosamente, teríamos um caso de convocação de uma narrativa religiosa para o universo das linguagens artísticas cênicas (que também são sonoras, visuais etc.). O outro exemplo seria o espetáculo de dança Gira, também de 2017, da magistral companhia de ballet "Grupo Corpo", que foi consagrado ao orixá Exu. Gira, que por natureza funciona como um paratexto do espetáculo, no universo ritual das religiões de matriz africana, como sugere o próprio nome do espetáculo, indica movimento, uma

O que não quer dizer que se estabeleça, necessariamente. 
dança, "estar" nos domínios das linguagens corporais, que são expressões centrais nessas religiões. No primeiro exemplo, estamos muito provavelmente diante articulações entre a linguagem verbal (texto verbal) e o universo das linguagens do universo cênico (texto cênico). No segundo, teríamos, presumivelmente, um tipo de interconexão que se estabelece a partir de linguagens que se equivalem do ponto de vista de suas respectivas "manifestações" ou formas de expressões (a dança como texto).

Portanto, ao falarmos simplesmente em religião e teatro ou de religião e dança, como falamos de religião e literatura para delimitar certo campo de estudos, talvez estejamos recorrendo a noções imprecisas não só de religião, mas também de arte. No fundo, se religião e teatro, religião e dança e religião e literatura e todos os seus análogos constituem-se em campos de estudos, talvez fosse mais preciso dizer que se trabalha ou se projeta sobre um terreno no qual outra coisa não nos parece acontecer senão o encontro entre linguagens (ou encontro de textos regidos por codificações distintas). Pode ser que nos apercebamos de que a noção de religião e " $x$ ", sob tal prisma, possa parecer vaga.

Roman Jakobson (2003), nos Essais de linguistique générale, no capítulo dedicado aos aspectos linguísticos da tradução, demostrava certa atenção teórica diante das possíveis interconexão entre linguagens que portam sobre si codificações distintas. Ao que chamou de "traduction intersémiotique on transmutation", Jakobson pensava mais especificamente na “... interprétation des signes linguistiques au moyen de systèmes de signes nos linguistiques" (2003, p. 79). Partindo dessa mirada, nos pareceria mais adequado dizer que sob a possiblidade de se prospectar relações, interconexões etc. que se estabelecem entre tipos distintos de linguagens (textos) e seus diferentes níveis se definiria melhor não só os respectivos campos de estudos (alusiva e hipoteticamente mencionados), mas também o próprio estatuto daquilo que neles se apresenta como objeto: a interconexão entre textos (enquanto obras). Em lapidar formulação, Iouri Lotman recorda: “... l'art peut être décrit comme un langage secondaire et l'œuvre d'art, comme un texte dans ce langage" (1973, p. 37). Analogamente, outra coisa não nos parece ocorrer nos domínios do que chamamos de religião ${ }^{4}$.

\footnotetext{
4 Sobre as relações entre religião e linguagem, o texto do Prof. Paulo Augusto de Souza Nogueira, em solo brasileiro, é seguramente seminal. Cf. NOGUEIRA, Paulo Augusto de Souza. Religião e linguagem: proposta de articulação de um campo complexo. Horizonte, v. 14 , n. 42 , p. $240-261,2016$.
} 
As obras artísticas, no que concerne aos seus modos de funcionamento, são suscetíveis a regimes específicos. A esse respeito, Genette (2010) propõe, por exemplo, uma distinção entre os seus modos de manifestação. Para ele, as obras de arte são "classificadas" basicamente a partir dois regimes do ponto de vista da sua aparição: as obras autográficas e as alográficas. A pintura seria um exemplo do primeiro caso, enquanto a literatura se trata de um exemplo da arte alográfica. Já no que respeita à manifestação, a literatura pode "acontecer" por "(de)notação" / "inscrição", mas também por um tipo de vocalização (textos orais, etc...), e isso alteraria o tipo de aproximação teórica a ser feita. Sendo, portanto, a "(de)notação" a forma de inscrição que sinalizaria, segundo Genette, o modo específico de manifestação do texto literário (objeto alográfico), é a partir dela, em nossa ótica, que a materialidade do verbal torna-se mais concreta para o escopo das discussões que propomos.

Desse modo, se estamos falando de literatura(s), "langages secondaire" (LOTMAN, 1973, p. 36-37), parece-nos oportuno, uma vez mais, estabelecer uma aproximação com o universo teórico dedicado às linguagens verbais. Assim, para o que se segue tomaremos por empréstimo de Gérard Genette (2009) as noções de paratexto (aludida anteriormente) e bipertexto, e de Dominique Maingueneau (2009) a noção de cenografia.

\section{Ilustrações...}

Da economia das pinturas até as amplificações literárias encontramos um vasto repertório de elementos religiosos que desempenham funções importantes (personagens, intrigas etc.) nesses tipos de expressões artísticas e que podem, em nosso caso, se apresentar como pistas para pensar faces específicas das relações entre "religião e literatura" a partir da ótica que adotamos. Em favor da criação de uma zona de maior de estabilidade para os argumentos até aqui delineados, tomemos, por exemplo, as inúmeras recepções que as expressões artísticas (visuais, literárias, cênicas etc.) realizaram e ainda realizam acerca dos textos da Bíblia. Não seria nenhum absurdo admitir que, em um dado quadro sociocultural, os textos da Bíblia não sejam apenas textos que se restringem aos limites do regime verbal (literários etc.), mas antes escrituras sagradas.

$\mathrm{Na}$ tentativa de ilustrar o que foi dito até aqui, nos ocuparemos com alguns escritos que, ao prospectarmos sobre eles o cumprimento da função artística, singularizam-se pelo seu espectro cômico. Visitaremos, brevemente, três histórias da autoria de Woody Allen e que foram coligidas no quarto 
capítulo de Without Feathers - The Scrolls 5 . Publicada originalmente em 1975, a obra reúne dezoito capítulos curtos e seu título é uma alusão a Hope is the thing with feathers, um dos mais conhecidos poemas de Emily Dickinson ${ }^{6}$. Como sabemos, o cineasta e escritor norte-americano não raramente convoca em sua produção artística elementos ostensivamente pertencentes à religião. Caracteres do judaísmo, por exemplo, apresentam-se muitas vezes como material artístico em seus filmes, o que assinala uma inequívoca consideração dispensada à religião ${ }^{7}$. E esse também parece-nos ser o caso das três histórias contadas em The Scrolls.

Dos meios que podem desencadear/provocar o riso enquanto efeito estético, o que em nossa ótica se configura como um possível gesto (dentre muitos outros) em direção ao que Sontag chamou de uma "erótica da arte", o texto literário - "relation in absentia entre un auteur et un lecteur partageant un intérêt”, assim postula Jean-Marc Moura (2010, p. 43) - se apresenta como médium mais improvável. Sob tal ângulo, talvez estejamos em desvantagem se compararmos os textos literários, por exemplo, com as rápidas e eficazes sketches cômicas de palco, mas prossigamos. A nossa aposta, contudo, reside no seguinte:

[...] les écrits comiques et humoristiques appartiennent à l'ensemble singulier des textes provoquant une réaction corporelle reconnaissable ; comme le fantastique, le mélodrame et le pornographique, ils visent une manifestation physiologique perceptible de l'état du lecteur (MOURA, 2010, p. 4).

5 The Scrolls, por mais afeito que seja ao universo cênico, emerge sob o regime da linguagem verbal. Esse ponto pode parecer lateral e mesmo suscetível a críticas (e não negaremos que o seja), mas as histórias ali reunidas, ao menos do ponto de vista do tipo da sua "manifestação", por meio da qual seria possível fixar o seu aparecimento enquanto obra (ao menos para nós), nos permite fazer essa afirmação. O mesmo poderíamos admitir acerca dos textos que, por transparência (transtextualité ou transcendance textuelle), segundo Genette (1982, p. 7), apresentam, desde o interior de The Scrolls, os indícios necessários de sua explícita convocação, pois os textos bíblicos (parece-nos aqui ser o caso) também se manifestam sob (de)notação (GENETTE, 2010).

6 O primero capítulo de Without Feathers, "Selections of the Allen Notebooks", cita o poema: "How wrong Emily Dickinson was! Hope is not 'the thing with feathers.' The thing with feathers has turned out to be my nephew. I must take him to a specialist in Zurich" (ALLEN, Without Feathers, p. 9).

7 A próprio do chamado bumour juif (não raramente elevado à categoria de gênero artístico), o erudito e brilhante trabalho de Judith Stora-Sandor é uma importante referência. Cf. STORA-SANDOR, Judith. L'humour juif dans la littérature. Paris: PUF, 1984. 
Assim sendo, a criação artística dos textos de Woody Allen, cuja intencionalidade estética pressupomos existir, reivindica a existência de um leitor que seja capaz de rir (cf. MOURA, 2010). Postulamos, portanto, um tipo de passagem do texto ao riso, pois

Le texte 'pour rire' se caractérise par une posture d'énonciation (représentée et différée) instituant un risible - l'élément dont on rit - en même temps qu'un certain rapport à celui-ci, posture supposant partenaire, médiation, intentionnalité (MOURA, 2010, p. 73).

Para Jean-Marc Moura (2010, p. 74), um texto cômico supõe uma interação entre três instâncias, segundo uma estrutura triangular, e que são as seguintes: "le rieur (l'ethos), le lecteur ou le public qu'il vise (lecteur, public impliqué) e le risible (l'objet du rire)". A manutenção dessa dimensão triádica no horizonte dos textos de Woody Allen talvez reforce a ideia segundo a qual a eventual convocação dos textos da Bíblia Hebraica pela criação literária, pelo menos no caso dos textos que mais adiante traremos à baila, não seja acidental, mas antes conduzida por uma "intention esthétique" (GENETTE, 2010), cujo possível efeito seja a transparência do risível e a provocação do riso nos leitores.

O riso esperado também é articulado pelo paratexto. Pensado por Genette (2009, p. 12) como sendo uma soma do que chamou de "epitexto+peritexto", o paratexto nos textos verbais opera mais plenamente em função dos seus possíveis destinatários e designa um amplo conjunto de elementos que participam do universo de uma obra (nome ou pseudônimo do autor, títulos, epígrafes, prefácios, intertítulos etc.). No caso em questão, em uma rápida comparação entre pelo menos duas das várias edições de Without Feathers, veremos que na de 1983 (a primeira data de 1975) há uma intervenção no nível do procedimento editorial, que é justamente a inclusão da inscrição "The hilarious bestseller by" na capa da obra. Uma edição de 1988 também reforça uma possível entrada no texto sob a condução dos paratextos. Nela figura a seguinte inscrição: “Very, very funny Punch"'. Esses elementos alcançam o leitor antes mesmo que ele alcance o texto pela leitura. 


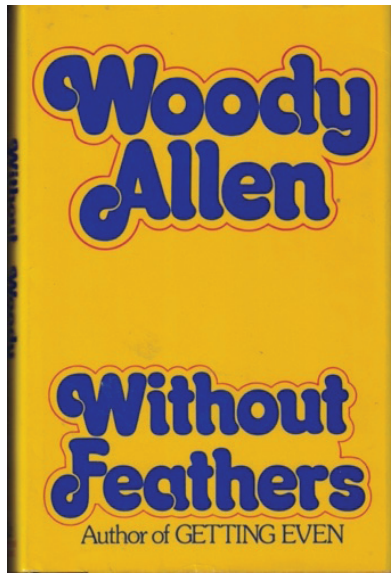

1975

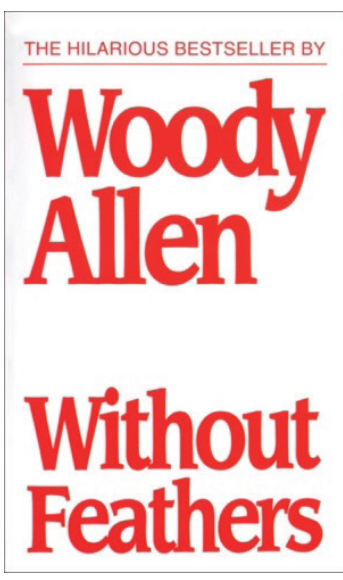

1983

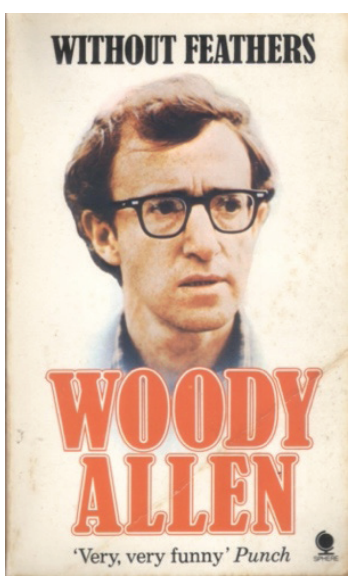

1988

"'Zona indecisa', entre o dentro e o fora", como muito bem afirma Genette, o paratexto "oferece a cada um a possibilidade de entrar, ou retroceder” (GENETTE, 2009, p. 9-10). É nesse sentido que o leitor/ espectador se tornar um tipo de cumplice do texto com o qual se confrontará. Sendo conduzido do "exterior" para o interior do texto, um tipo de expectativa se cria antes mesmo da experiência com ele. No caso de Without Feathers, o nome do autor também se oferece como uma "franja do texto impresso que, na realidade, comanda toda leitura” (GENETTE, 2009, p. 10) - expressão que Genette recupera de Philippe Leujene. O nome autor pode cumprir uma função contratual. Woody Allen, sabemos, é um dos grandes nomes do universo do cômico norte-americano.

Se voltarmos nossas atenções para o rieur, seria possível afirmar que o leitor/espectador pode construir um horizonte de expectativa sob a consideração do universo das criações artísticas do cineasta-escritor. The Scrolls (paratexto que pode funcionar como intertítulo em relação a $W$ ithout Feathers, mas que também funciona como título e "prólogo" para as histórias chamadas de "One", Two, "Three", as quais, por sua vez seriam intertítulos de "The Scrolls" - cf. GENETTE, 2009, p. 259) se inicia com um tipo de "prólogo" destinado a fornecer algumas informações acerca das escrituras que serão, a seguir, apresentas. Sob características da escrita jornalística, o que em princípio reivindica, do ponto de vista discursivo, certa autoridade para quem fala e sobre o que se fala, esse "prólogo" que antecede as três breves histórias contadas promove, "de largada", uma guinada em direção aos mecanismos tão 
caros ao cômico. Se Henri Bergson (2018, p. 40) estiver correto ao admitir que certa disposição ao riso pode ocorrer face ao que há de "involuntário numa mudança" (de estado, diríamos) - e um dos exemplos a que recorre é exatamente o dos passantes que riem de um homem que tropeça e cai -, a queda do pastor numa caverna por ocasião de uma viagem pelo "Gulf of Aqaba"8 (ALLEN, 1983, p. 24) e que o leva a descobrir, acidentalmente, seis rolos dentro de jarros de argila, assim informa o prólogo, introduz na narrativa um evento-tipo que serve como chave para o risível. Mas a busca pela instalação do cômico não se encerra com a queda do pastor distraído e sua perna quebrada. Junto com os jarros de argila, o pastor-viajante encontra também dois tickets para um "ice show" (ALLEN, 1983, p. 24). Nesse ponto, o texto põe em cena aquilo que Patrick Charaudeau (2006, p. 19-41) chama de "loufoquerie", que se caracterizaria pela evidente ausência de relação direta ou de real oposição entre os universos que se encontram no texto. Que relação direta pode haver entre jarros com rolos de pergaminhos "antigos" e dois tickets para shows em pista de gelo?

A origem, a autoria e a autenticidade dos manuscritos - questões clássicas nos estudos de textos religiosos antigos - é introduzida no jogo textual. Os arqueólogos, que podem simbolizar a autoridade científica, aparecem como os responsáveis pela datação dos manuscritos em 4000 anos antes de Jesus Cristo. É preciso destacar que a introdução de informações dessa natureza, por mais normal que possa parecer, é utilizada como um tipo de artifício implicado à criação artística, cuja finalidade é dotar o que se diz de certas características indispensáveis a um tipo específico de discurso. É nesse sentido que Dominique Maingueneau (cf. MAINGUENEAU, 2009, p. 249-265), introduzindo a noção de "cenografia" ao refletir sobre a adequação do conceito de "situação de enunciação" no horizonte dos textos literários, afirma que o leitor, no caso dos textos literários, "se vê apanhado numa espécie de armadilha”, porque o texto que lhe chega em primeiro plano é assim moldado por ela (cenografia) e não pela sua cena englobante e pela sua cena genérica. No caso em questão, a cenografia que se revela procura induzir o leitor/espectador à percepção do caráter jornalístico do texto, quando no fundo, do ponto de vista das cenas englobante e genérica, ele consigna-se aos universos literário e cômico, respectivamente. Se tomarmos "o prólogo" como referência, veremos que as demais cenas (genérica e englobante) se infiltram

\footnotetext{
8 Possível alusão às histórias que revestem a descoberta dos manuscritos de Qumran?
} 
na cenografia "jornalística”. Ou seja: o texto quer explorar a clássica tensão entre os regimes sério e cômico dos textos. O que se apresenta ao leitor/ espectador, do ponto da cenografia construída, seria um texto meramente informativo. Porém, em decorrência de um possível deslocamento de sua atenção para os elementos estranhos à própria cenografia, o que se quer é situar o leitor/espectador diante do que pode desencadear o riso.

Embora não se aplique tão somente aos textos cômicos, os segmentos narrativos/cênicos são tecidos a partir de estratégias que visam a fazer do destinatário (leitor/espectador) "un complice" da drôlerie que se instala. A obra não se destina a outra coisa. A cenografia que se constitui está permeada de dispositivos cômicos. A alternância do risible, o que confere certa rapidez aos segmentos narrativo/cênicos, parece-nos ser uma das estratégias utilizadas pelo comediante. No caso da queda, a hipótese do riso se dirige ao pastor, mas com a evocação dos arqueólogos, o risível se desloca possivelmente à suposta autoridade que as ciências representam. Soma-se ainda a essa alternância a inclusão de dimensões insólitas, pois ao evocar a história dos israelitas como pano de fundo dos manuscritos, o texto associa certo massacre a que teriam sido submetidos não aos seus inimigos ou perseguidores, mas aos seus "benfeitores" (ALLEN, 1983, p. 24).

A cenografia é nutrida ainda por outros elementos cômicos. O deslocamento dos manuscritos do seu possível revestimento sacro seria mais um exemplo. A autenticidade dos manuscritos, que são redigidos a partir de um mescla "de sumério, de aramaico e de babilônico", o que por certo funciona como elemento orientador do leitor/espectador em direção ao universo das línguas bíblicas semíticas, é posta em dúvida após se observar, assim é dito no "prólogo", a repetição da palavra "Oldsmobile". A infiltração desse vocábulo no "prólogo", e que recupera aquilo que acima chamamos de "loufoquerie", seria mais um elemento de indução ao acionamento do risível. Fora dos domínios do cômico, esse vocábulo significa (sem o prejuízo de outras possíveis sentidos) a marca de carros norte-americana fundada por Ramson Eli Olds, o que reforça a presença de dispositivos cômicos na cenografia jornalística. Por outro lado, se decompusermos o vocábulo (Olds+mobile), veremos que "mobile" indica não só movimento, mas também artefato, objeto. Nesse sentido, a expressão funcionaria como um tipo de referência aos textos da Bíblia Hebraica enquanto artefatos antigos. 


\section{"The Scrolls..."}

As cenografias das três histórias de The Scrolls são claramente marcadas pelas infiltrações de elementos que sugerem comicidade. O que chega ao leitor/espectador no primeiro plano são textos que pretendem simular a presença dos textos bíblicos. Por meio da convocação de personagens, narrativas, intrigas etc. bíblicas, as três histórias estabelecem claramente relações transtextuais com determinados textos da Bíblia Hebraica, o que reforça a criação de uma atmosfera que orienta a expectativa do leitor/ espectador para o universo das narrativas sagradas. É nessa cenografia bíblica que se constitui a envergadura cômica dos textos. O que vemos emergir seria um tipo de "intertextualité anarchique" (MOURA, 2010, p. 118). Tudo, porém, o que se encontra à disposição na construção das cenas subordinase à relação risível-riso. Nas histórias, tão somente chamadas de "One", "Two", "Three", o Senhor, Jó, Abraão, Isaac e Sara, por exemplo, escorrem dos textos da Bíblia e infiltram-se nos The Scrolls de Woody Allen. É nesse ponto que o conceito de hipertexto em Genette tornar-se iluminador, pois os hipotextos (Texto A - os textos da Bíblica Hebraica) surgem explicitamente, sob uma operação de transformação, nos hipertextos (Texto B - os textos de The Scrolls). Por exemplo:

$$
\text { Texto A - Jó } \longrightarrow \text { Texto B - "One" (The Scrolls) }
$$

A primeira história (ALLEN, 1983, p. 25-26) inicia-se com a fórmula "... and the Lord...", o que convoca o leitor/espectador para o universo das narrativas bíblicas. Na sequência, de súbito, após se enunciar uma aposta com Satã, o Senhor projeta-se sobre Jó, golpeia-lhe a cabeça, a orelha, empurralhe num tipo de molho viscoso (na tradução francesa Jó aparece dentro um caldeirão de "sauce Béchamel") e abate suas vacas, o que leva a Jó a bramir:

"Why doth thou slay my kine?" (ALLEN, 1983, p. 25)

Mas a preocupação de Jó não poderia ser mais prosaica: a questão é o prejuízo causado pelo Senhor.

As cenas são rápidas e descontinuas. O imprevisível (Sara, sem causa aparente, por exemplo, é ungida/consagrada com um taco de polo pelas mãos de um anjo) e a atenção sobre os corpos das personagens ao criar "caracteres" 
de estado (o pastor que cai, o Jó besuntado, o Senhor ensandecido, bufão e descontrolado) são alguns dos recursos postos em operação e que visam a orientar os leitores/espectadores para o risível. Como bem sinaliza Jean Sareil (1985, p. 105), "dans la désordre du comique [...] les héros sont inconsistants, maladroits et ridicules".

As marcas do insólito estão por toda parte. Jó, que na primeira cena aparece sendo esbofeteado e besuntado de molho, surge, mais à frente, segurando o Senhor pelo pescoço:

And once the Lord, while wreaking havoc upon his faithful servant, came too close and Job grabbed him around the neck and said, "Aha! Now I got you! Why art thou giving Job a hard time, eh? Eh? Speak up!" (ALLEN, 1983, p. 25)

Esses segmentos narrativos/cênicos, ainda que rápidos, parecem demostrar um outro tipo de alternância dos núcleos cômicos (em ziguezague), de acordo com o protagonista de uma determinada cena.

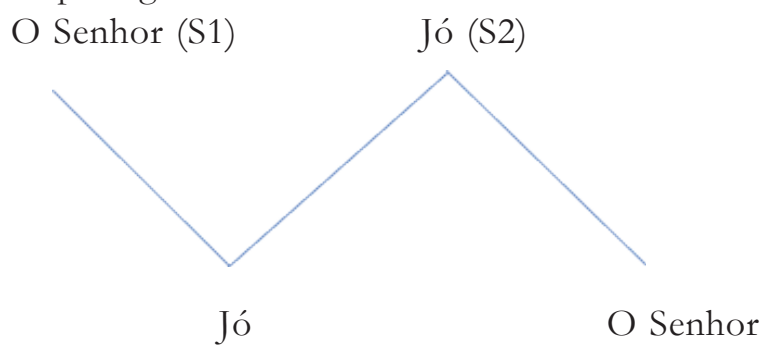

\begin{tabular}{|c|l|}
\hline $\begin{array}{c}\text { S1 - segmento narrativo/cê- } \\
\text { nico }\end{array}$ & $\begin{array}{l}\text { And the Lord made an bet with Satan to test } \\
\text { Job's loyalty and the Lord, for no apparent rea- } \\
\text { son to Job, smote him on the head and again on } \\
\text { the ear and pushed him into an thick sauce so as } \\
\text { to make Job sticky and vile and then He slew a } \\
\text { tenth part of Job's kine and Job calleth out: "Why } \\
\text { doth thou slay my kine? Kine are hard to come } \\
\text { by. Now I am short kine and I'm not even sure } \\
\text { what kine are". }\end{array}$ \\
\hline $\begin{array}{c}\text { S2 - segmento narrativo/cê- } \\
\text { nico }\end{array}$ & $\begin{array}{l}\text { And once the Lord, while wreaking havoc upon } \\
\text { his faithful servant, came too close and Job } \\
\text { grabbed him around the neck and said, "Aha! } \\
\text { Now I got you! Why art thou giving Job a hard } \\
\text { time, eh? Eh? Speak up!" }\end{array}$ \\
\hline protagonista da ação) - Jó
\end{tabular}


Se a atenção do leitor/espectador é atiçada pela drôlerie, pelo ridículo, pelo insólito etc., o movimento que acima tentamos demostrar, ao menos na primeira história, dirige o olhar do receptor para a personagem-vítima, que no ambiente do segmento narrativo/cênico se tornaria, em tese, alvo do riso. Na primeira, o riso é possivelmente dirigido a Jó. Já na segunda, é provável que a atenção do leitor/espectador esteja sobre o Senhor.

A segunda história, “Two” (ALLEN, 1983, p. 26-27), convoca explicitamente a narrativa de Gn 22. Ao ouvir de seu pai, Abraão, em plena madrugada, que durante um sonho o Senhor lhe ordenara sacrificar seu próprio filho ("I have had an dream where the voice of the Lord sayeth that I must sacrifice my only son, so put your pants on"), Isaac devolve-lhe de imediato:

"So what did you say?" (ALLEN, 1983, p. 26)

E Abraão responde:

"What am I going to say?" [...] "I'm standing there at two a.m. in my underwear with the Creator of the Universe. Should I argue?" (ALLEN, 1983, p. 26)

\section{$[\cdots]$}

"The faithful do not question. Now let's go because I have a heavy day tomorrow". (ALLEN, 1983, p. 26)

O Senhor e Abraão dialogam bastante nessa história, o que demostra, entre outros aspectos, certa envergadura dramática do texto. Após a divina interdição tão conhecida, e que na história de The Scrolls é reeditada, há uma sequência de falas na qual o elemento sério (o sacrifício) sofre um superlativo deslocamento. Temos aí uma demonstração dos hipertextos em operação.

And Abraham said, "But thou said -!"

"Never mind what I said", the Lord spake. "Doth thou listen to every crazy idea that comes thy way?" [...]

"I jokingly suggest thou sacrifice Isaac and thou immediately runs out to do it".

[...] “See, I never know when you're kidding." (ALLEN, 1983, p. 27)

Se o Senhor aparece - aos olhos de Abraão - como "blagueur" de mau gosto, aos olhos do primeiro, Abraão não alcançou o sentido da ordem: 
“No sense of humor. I can't believe it." (ALLEN, 1983, p. 27).

A terceira história (ALLEN, 1983, p. 27-28) narra a insatisfação de um comerciante de roupas com suas vendas. Nela, se existe a presença de outros prototextos bíblicos, eles não são tão evidentes, com exceção de uma explícita convocação do Salmo 23 ao final da história. O interlocutor do Senhor não entende o porquê do fracasso de suas vendas:

"Lord, why hast thou left me to suffer thus? All mine enemies sell their goods except I. And it's the height of the season. My shirts are good shirts. Take a look at this rayon. I got button-downs, flare collars, nothing sells. Yet I have kept thy commandments $[\ldots]$ "

And the Lord heard the man and said, "About thy shirts..."

"Yes, Lord", the man said, falling to his knees.

"Put an alligator over the pocket". (ALLEN, 1983, p. 27)

A solução apresentada por Deus é tão absurda que causa certo espanto até mesmo no próprio comerciante:

"Pardon me, Lord?" (ALLEN, 1983, p. 27)

A "fórmula mágica", que por certo visa a orientar o leitor/espectador para o risível sob a face do absurdo, é completamente ilógica e exala certo surrealismo:

"Just do what I'm telling you. You won't be sorry". And the man sewed on to all his shirts a small alligator symbol [...]”. (ALLEN, 1983, p. 27-28)

Aos moldes do que acontece com a expressão "Oldsmobile", o símbolo do crocodilo sugere, no nível da plaisanterie, é claro, uma referência à grife francesa Lacoste.

\section{Considerações não conclusivas}

Essas histórias se articulam a partir de tableaux rápidos, às vezes sinuosos, descontínuos e imprevisíveis. O que talvez seja preciso não perder de vista, tão somente, é que dos textos de Woody Allen - pelo menos os que 
aqui foram brevemente convocados e que utilizamos para fins de ilustração - é possível entrever uma complexa poética a partir da qual, em distintos aspectos, o cômico e os textos bíblicos fazem de The Scrolls, conjuntamente, um possível objet attentionnel. A possível constituição desses textos em objet attentionnel, sob as implicações dos textos bíblicos em suas respectivas poéticas, deve-se, em parte, à oposição sério/cômico que se estabelece de modo mesclado e indissolúvel ao nível da recepção. Se uma atenção especial é projetada sobre esses textos em razão de personagens, intrigas etc. provenientes dos domínios da Bíblia em favor da criação artística, talvez nos seja oportuno lembrar uma vez mais as seguintes palavras de George Steiner:

[...] Como ficariam nuas as paredes de nossos museus se delas fossem retiradas as obras de arte que representam ou se referem a temas bíblicos. Que silêncio se faria em nossa música ocidental, desde os cantos gregorianos até Bach, desde Händel até Stravinsky e Britten, se baníssemos as referências bíblicas de seus textos, de suas dramatizações e de seus temas. O mesmo aconteceria com a literatura ocidental. Nossa poesia, nosso drama, nossa ficção ficariam irreconhecíveis se omitíssemos a presença constante da Bíblia (STEINER, 2018, p. 109).

Essas incontáveis reverberações dos textos da Bíblia, tão precisamente aludidas por Steiner, apontam seguramente para a existência de um tipo de convocação calculada desses textos pelas expressões artísticas.

\section{Referências}

ALLEN, Woody. Dieu, Shakespeare et moi. Paris : Éditions du Seuil, 2001.

ALLEN, Woody. The Scrolls. In: Without Feathers. New York: Ballantine, 1983, p. 24-28.

BARCELLOS, José Carlos. Literatura e espiritualidade: uma leitura de Jeunes Années, de Julien Green. Bauru: EDUSC, 2001.

BARCELLOS, José Carlos. O drama da salvação: espaço autobiográfico e experiências cristã. Juiz de Fora: Subiaco, 2008.

BERGSON, Henri. O riso: ensaio sobre o significado do cômico. São Paulo : Edipro, 2018. CHARAUDEAU, Patrick. Des catégories pour l'humour. Questions de communication, n. 10, p. 19-41, 2006.

CHENU, M.- D. La littérature comme "lieu" de la théologie. Revue des sciences philosophiques et théologiques, v. 53, n. 1, p. 70-80, 1969.

GENETTE, Gérard. L’Guvre de l'art. Paris: Éditions du Seuil, 2010. 
GENETTE, Gérard. Palimpsestes: la littérature au second degré. Paris: Éditions du Seuil, 1982. GENETTE, Gérard. Paratextos editoriais. Cotia: Ateliê Editoral, 2009.

JAKOBSON, Roman. Essais de linguistique générale. Paris: Minuit, 2003.

JAKOBSON, Roman. Huit questions de poétique. Paris: Éditions du Seuils, 1977.

JOSSUA, J.-P. Pour une histoire littéraire de l'expérience religieuse. Paris: Beauchesne, 1985. v. 1.

LOTMAN, Iouri. La structure du texte artistique. Paris: Éditions Gallimard, 1973.

MAINGUENEAU, Dominique. Discurso literário. São Paulo: Contexto, 2009.

MOURA, Jean-Marc. Le sens littéraire de l'humour. Paris: PUF, 2010.

NOGUEIRA, Paulo Augusto de Souza. Religião e linguagem: proposta de articulação de um campo complexo. Horizonte, v. 14, n. 42, p. 240-261, 2016.

SAREIL, Jean. L'Écriture comique. Paris: PUF, 1985.

SONTAG, Susan. Contra a interpretação e outros ensaios. São Paulo: Companhia das Letras, 2020.

STEINER, George. Prefácio para Bíblia Hebraica. In: Nenhuma paixão desperdiçada. 2. ed. Rio de Janeiro: Record, 2018.

STORA-SANDOR, Judith. L'humour juif dans la littérature. Paris: PUF, 1984.

WALTON, Kendall. Catégories de l'art. In: GENETTE, Gérard. Esthétique et poétique. Paris: Éditions du Seuil, 1992.

Submetido em: 21-9-2021

Aceito em: 11-10-2021 